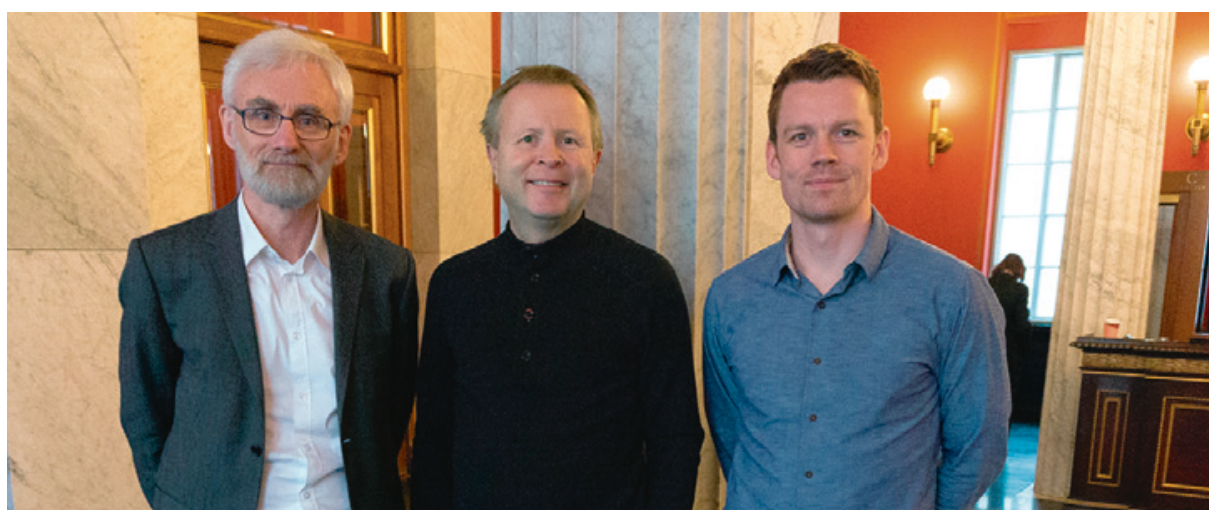

Kristian Hveem, Torbjørn Omland, Magnus Nakrem Lyngbakken. Foto: Christian Jonasson, Norges teknisknaturvitenskapelige universitet/HUNT forskningssenter

\section{Lave troponinnivåer hos røykere}

Røykere har lavere troponin I-nivåer i blodet enn ikke-røykere.

Dette viser en ny norsk studie.

Kardiale troponiner er proteiner som benyttes for å diagnostisere hjerteinfarkt, men som også har vist seg å være sensitive markører for tidlig hjerteskade hos individer uten tidligere kjent kardiovaskulær sykdom. Ved hjelp av nye, såkalte høysensitive analysemetoder kan man nå fange opp svært lave konsentrasjoner av troponiner i blodet hos store deler av en frisk befolkning. Sammenhengen mellom røyking, troponin I-nivå og kardiovaskulære hendelser ble nylig undersøkt i en norsk studie (1).

Troponin I ble målt hos rundt 3800 ikkerøykere, 2300 tidligere røykere og 2500 røykere som deltok i Helseundersøkelsen i Nord-Trøndelag (HUNT2). Røykerne hadde signifikant lavere troponin I-nivåer enn ikke-røykerne og de tidligere røykerne, med medianverdier på henholdsvis $2,9 \mathrm{ng} / 1$, $3,2 \mathrm{ng} / \mathrm{l}$ og 3,4 ng/l (begge $\mathrm{p}<0,001$ ).

Assosiasjonen mellom troponin I-nivå og kardiovaskulære hendelser var sterkere hos dem som aldri hadde røykt eller hadde sluttet å røyke enn hos røykerne. Hos røykere ga troponin I-nivå sammen med en mye brukt risikoskår for kardiovaskulær sykdom (Framingham Cardiovascular Disease risk score) ingen økt prognostisk informasjon.

- I utgangspunktet skulle man tro at røykerne ville ha høyere troponin I-nivåer på grunn av den skadelige effekten tobakksrøyking har på det kardiovaskulære systemet, sier Magnus Nakrem Lyngbakken, som er studiens førsteforfatter. - Dette kan skyldes at røykere generelt har lavere muskelmasse enn ikke-røykere. Mindre muskelmasse i venstre hovedhjertekammer vil kunne gi lavere troponinnivåer. Det er også mulig at de ulike innholdsstoffene i tobakksrøyk kan påvirke troponinmetabolismen, slik at troponinnivåene blir lavere hos dem som røyker, sier Lyngbakken.

- Sammenhengen mellom troponinnivå og kardiovaskulær sykdomsrisiko hos røykere, som kom frem i ujusterte analyser, falt bort når vi justerte for kjønn, alder og andre kardiovaskulære risikofaktorer, sier Lyngbakken. - Fra tidligere har vi vist at sammenhengen mellom troponinnivå og kardiovaskulære hendelser er sterkest for hjertesvikt og død og mindre sterk for hjerteinfarkt. I vår studie var hjerteinfarkt oftere hos røykere enn i de andre gruppene den første kardiovaskulære hendelsen. Dette kan være med på å forklare den lave prognostiske verdien av troponinnivå hos røykere.

\section{Forskergruppen}

Hjerte-lunge-forskningsgruppen Cardiothoracic Research Group ved Akershus universitetssykehus er en ung forskergruppe som har som overordnet mål å utvikle persontilpasset behandling til pasienter med hjertesykdom. Gruppen ledes av professor Torbjørn Omland og førsteamanuensis Helge Røsjø, som begge er medforfattere i denne studien.

Gruppens forskning omfatter basalmedisinske prosjekter, klinisk epidemiologiske studier, forskerinitierte randomiserte kliniske studier og epidemiologiske studier. Deres studier om kardiovaskulære biomarkører er publisert i flere ledende fagtidsskrifter, blant annet Circulation og Journal of the American College of Cardiology. I 2017 skal seks stipendiater i gruppen disputere. En av dem er Lyngbakken, som er lege ved Medisinsk avdeling, Akershus universitetssykehus.

\section{Kari Tveito}

Tidsskriftet

\section{Litteratur}

1. Lyngbakken MN, Skranes JB, de Lemos JA et al. I concentrations and cardiovascular events in the general population: The HUNT study. Circulation 2016; 134: 1962-72 Impact of smoking on circulating cardiac troponin
Ordforklaringer

Troponin I: Hjertemuskelprotein som danner troponinproteinkomplekset sammen med troponin $\mathrm{C}$ og troponin T. Måling av troponin I og T brukes klinisk i diagnostikk av hjerteinfarkt.

Framingham Cardiovascular Disease Risk Score: Skår utviklet for å forutsi tiårsrisiko for kardiovaskulære hendelser, slik som kardiovaskulær død, hjerteinfarkt og hjertesvikt.

HUNT: Helseundersøkelsen i Nord-Trøndelag, etablert i 1984. Dette er Norges største pågående prospektive kohortstudie med mer enn 120000 deltakere fra Nord-Trøndelag. 